\title{
The Students' Voice on The Regulation of National Exams Abolition
}

\author{
Airyn Eki Shandy ${ }^{1 *}$ and Ernawati ${ }^{2}$ \\ ${ }^{1,2}$ Postgraduate Program of English Education, Universitas Muhammadiyah Parepare, Indonesia \\ *airynekishandy@gmail.com
}

\begin{abstract}
The National Exam is an evaluation system for national education standards and the equality of education quality between regions conducted by the Center for Educational Assessment. As a result of the COVID-19 pandemic in Indonesia in March 2020, there has been discourse from various parties to abolish the National Examination. But then this was not just a discourse, the Government officially abolished the National Examination (UN). This decision was taken after the Minister of Education and Culture Nadiem Makarim held an online meeting with Commission X DPR RI. This was conveyed openly via video conference media by the president and the Minister of Education and Culture. This is what the researcher considers to conduct this research using the qualitative research by using interview model. The sample of this study was a randomly selected sample consisting of several students ranging from SMP (Junior High School) - SMA (Senior High School) /SMK (Vocational School) and several students from various Universities who were willing to give their opinions with the consideration that the informants used as samples were considered to know best what the researcher was looking for. Some samples were given a interview through private chat, and some were done by face-to-face by online which was like telling a story.
\end{abstract}

Key words: Covid-19 pandemic, elimination of national exams, interview method, national exams.

\section{Introduction}

In the implementation of learning in Indonesia starting from Elementary School, Junior High School to Senior high school/ vocational high school/ equivalent, students will of course face a final test, which determines student graduation, namely the national exam. The evaluation tool for final learning outcomes for education, called the national exam (UN) is used to find out information on how well students understand the learning that has been done previously. The national exam is an evaluation system for education standards in Indonesia [1]. Another of them explain that the national exam is an effort by the government to evaluate nationally the level of education by setting national education standards. Therefore, the results of the National Examination held by the State are an attempt to map educational problems in order to formulate and make various educational policies nationally [2]. Another article state that on evaluative national exams defines the national exam as an activity to measure, assess, and evaluate learning outcomes. Measurement is an activity to quantify an object or symptom, while assessment or assessment is an activity to interpret the measurement results in the form of numbers. Assessment is also defined as an activity to determine the learning achievement of students. The definition of educational evaluation is an activity to make judgments on the results of the assessment, such as passing or not and succeeding or not. Evaluation 
is also interpreted as an activity to determine the learning achievement of a group, such as a class or school. So, measurement, assessment, and evaluation of education are hierarchical. Evaluation requires information on the results of the assessment, while assessment requires data on measurement results. The National Examination (UN) is a national standard evaluation system for primary and secondary education conducted by the Center for Educational Assessment, the Ministry of National Education in Indonesia based on the Law of the Republic of Indonesia number 20 of 2003 which states that in the context of controlling the quality of education nationally, evaluation is carried out as a form of accountability for administrators. education to interested parties [3].

Since 2003, the national examination has received various criticisms, the national examination has become a controversy. Until 2020 yesterday, The Ministry of Education and Culture (Kemendikbud) decided to abolish the national exam (UN) and the equivalence exam in 2021. The decision is contained in the Circular Letter (SE) of the Minister of Education and Culture Number 1 of 2021 concerning the Elimination of National Examinations and Equivalence Exams and Implementation of School Exams in Emergency Periods Spread of Corona Virus Disease (Covid-19), The SE was signed by Minister of Education and Culture Nadiem Anwar Makarim on February 1, 2021 and addressed to governors, regents, and mayors throughout Indonesia [4]. Corona Virus also known as Novel Corona Virus, was first discovered in the city of Wuhan, China in November 2019. This virus can spread quickly and cause an outbreak of pneumonia that spreads globally, so it is called Coronavirus Disease (covid-19). Covid-19 has been declared a global pandemic by the World Health Organization (WHO) (Betty et al., 2021) [5]. Another perceptions said that COVID-19 is a new group of viruses named corona virus, then officially accepted as COVID-19 is the event of the spread of coronavirus disease 2019 or COVID-19 throughout the world [6].

Of course, with the abolition of the national exam, there are pros and cons for stakeholders, the government as well as education actors, namely teachers and students. there are those who strongly agree with the abolition of this national exam and there are also those who do not agree. A group of stakeholders even said that "with the abolition of the national exam will give birth to soft students". But some students think otherwise.

The study entitled "The Students' Voice On The Regulation Of Abolition Of National Exams" examines the students' voices regarding the abolition of the national exam and its impact on the students themselves". The researcher did this by using the Interview method by asking questions to some of students via private text messages, and giving questions to the others students by face-to-face by media online/ media social. Imam Ghosali state that Interview Method It is a data collection technique in which the researcher directly engages in a dialogue with the respondent to obtain information from the respondent. Basically, there are two types of interviews, namely structured interviews and unstructured free interviews. A structured interview is a type of interview that is structured in detail. An unstructured interview is a type of interview that only contains an outline that will be asked [7]. This research was conducted online in order to follow strict government regulations regarding COVID-19.

The researcher did this by using the Interview method by asking questions to some of students via private text messages, and giving questions to the others students by face-to-face by Google Meet. Google Meet is an application from Google that provides video communication services (conferences) that can be used for online meetings or face-to-face meetings. Google Meet is a great feature that is very useful for conducting meetings or face-to-face online with users spread all over the world [8]. The researcher conducted this research because the government's decision that became widely discussed regarding the abolition of the national exam, so this research is important. With the abolition of the national exam will it have a good or bad impact on education actors, especially the students. The researcher wants to know the voices of students regarding the abolition of the national exam that has been set by the minister of education.

The results of the research shows that the abolition of the National Examination declared by Nadiem as the minister of education is the right step and of course it has a good impact on students taken by the government in the world of Indonesian education. There were a lot of participants who expressed agreement with government regulations on the abolition of the National Examination. Most of them thought that the absence of the National Examination gave a comfortable impression in learning to students, students could focus more on learning-centered learning according to the schools in their area and students would certainly be more relaxed in what fields they mastered without having to focus on subjects in the national exam only. They will be able to further develop themselves according to their respective skills. National standards that are made nationally regardless of the area of the students will make students confused or even stressed. With the regulations regarding the abolition of the National Examination, students feel very relieved.

\section{Methodology}

This research was applying qualitative research. The method used by the researcher in this research was collective case study method. Qualitative research is a research method to explore and understand the meaning that some individuals or groups of people think come from social or human problems [9]. Another perceptions defines qualitative research as research that aims to understand the phenomena experienced by research subjects. It is more appropriate and suitable to be used for researching matters relating to research on the behavior, attitudes, motivations, perceptions 
and actions of the subject [10]. Therefore, this research would be conducted in order to obtain in depth to find out The Students' Voice On The Regulation Of Abolition Of National Exams.

The researcher using Interview system by giving questions to students randomly by sending them by private chat/ message, and giving questions direct face-to-face by online. In order to get deep information about students' perception about The Regulation Of Abolition Of National Exams.

The sampling technique in this study used purposive sampling. Purposive sampling, namely: sampling activities with the consideration that the informants used as samples are considered to know best what the researcher is looking for. The participants in this research were consists of several sample of the student at SMK Negeri 3 Parepare, SMA Negeri 1 Model Parepare, SMK NEGERI 1 Sumbawa Besar NTB, SMP Negeri 1 Pangkajenne Sidrap. and several students from various universities who are willing to give their opinions. The researcher used total population sampling in taking sample.

To find out The Students' Voice On The Regulation Of Abolition Of National Exams, the researcher gave same interview to the students by online (by sending them a message by media online and doing a face-to-face by media online). The questions for interview consisted of 5 questions for students. The list of questions is structured in the form of an open question. This method is used to obtain data about students perceptions about The Regulation of Abolition Of National Exams

\section{Findings and Discussion}

This study aims to obtain students' perception toward Regulation Of Abolition Of National Exams. The process of collecting data applied questionnaire, questions was sending by private chat and also face-t-face by social media. The Researcher chose randomly students to be interviewed by face-to-face by media online, and also to be interviewed by sending a private chat.

To answer the research questions, the researcher conducted semi-structure interview with the students. The researcher has determined several questions related to the research. It aimed to know the Students' perception toward Regulation Of Abolition Of National Exams. The process of the interview shows an interesting answer from the participant. The researcher collected found result as follows:

The researcher had been drove a depth interview to the informants. The researcher asked about their perception toward Regulation Of Abolition Of National Exams. Based on the students' experiences after thought it, they gave various information regarding the questions.

\section{Q. : Can students' learning abilities be assessed effectively through national exams?}

P1q2. : Of course not, because the quality of education from Sabang to Merauke has never been equal so the national standard is too high for those who don't feel the quality of education is equal. I feel very stressed when I hear about the national exam. Previously, I faced a national exam and the questions contained in it were too heavy, meaning that I had not studied in depth

P2q2. : No, because students' abilities can only be seen and measured from what we like and our own curiosity.

P3q2. : Students' abilities are different, some are not smart but creative, intelligent, some are smart but only smart. so to measure the ability of students can be done with other tests based on our own abilities. because if the national exam is used as a benchmark for measuring the overall ability of students, many students will be depressed, depressed, sick because they only focus on the tension of passing or not passing.

P4q2. : I think no, because for students the national exam has become a pressure and of course the work is also forced, after the exam they will forget everything that has been done during the exam.

P5q2. : Maybe, but I hope that we are returned to the standards that exist in our area, especially in our schools, of course also with our passion as students, because we have different abilities.

P6q2. : No, because learning ability does not always need to be measured by the results of national exam scores. Assignments, group discussions, etc. are better able to improve students' learning abilities if in my opinion, this can develop both left and right brain work.

P7q2. : No, National Examination is less than optimal as a tool to improve the quality of education nationally. Because it is held at the end of the level, the results of the National Examination cannot be used to identify students' learning needs and provide assistance according to those needs. 
However in the interview session the participants told some their experience through the national exam and the impact on their own. The participants said in going through the national exam they felt tense.

Q. : Do you agree or disagree with government regulations regarding the abolition of the National Exams?

P195. : Yes, it was their best decision to abolish the National Exams.

P2q5. : I strongly agree. With the abolition of the national exam, students can focus more on learning centered on learning according to schools in our area.

P395. : Of course. We are the students will certainly be more relieved. What I mean is that students will not only focus on the subjects in the national exam. Because all this time that's what I feel, I get nervous when it's mentioned the subjects in the National Exams.

P4q5. : Yes, we will be able to develop ourselves according to our respective skills.

P595. : Actually I like the spirit that we have in facing the national exams but with the national exams students study under pressure. So here I say that actually the national exam is necessary but it doesn't have to be used as the subject of the assessment that determines the graduation of students.

P695. : Totally agree, but there must be a substitute exam for the national exam that meets our standards. For SMK schools not really need National Exam scores because in SMK what is needed is the value of students' creativity.

P795. : I agree with the abolition of the national exam. There's already a school exam. I prefer that the school determines my graduation. Because indeed I was in school for many years. For the national exam, we took a few days but got direct results from determining how many days it was. Even though the school understands our abilities better.

\section{Conclusion}

In the world of education, we are certainly no stranger to the national exam, which is a system for evaluating national education standards and the equality of quality levels of education between regions conducted by the Center for Educational Assessment (Depdiknas). However, then in March 2020 the Government officially abolished the National Examination (UN) and the equivalence test in 2021. The decision is contained in the Circular Letter (SE) of the Minister of Education and Culture Number 1 of 2021 concerning the Elimination of National Examinations and Equality Examinations and the Implementation of School Exams in the Emergency Period for the Spread of Corona Virus Disease (Covid-19). The SE was signed by Minister of Education and Culture Nadiem Anwar Makarim on February 1, 2021 and addressed to governors, regents, and mayors throughout Indonesia. This decision was taken after the Minister of Education and Culture Nadiem Makarim held an online meeting with Commission X DPR RI. This then became a very interesting discussion in the world of education, especially for students. many students expressed relief and agreed with the regulation, although there were some students who also agreed with holding national exams continuously.

Based on the results of interviews conducted by researchers, the results of the interviews showed the answers to perceptions toward Regulation Of Abolition Of National Exams, the researchers assume that most of students expressed agreement with government regulations on the abolition of the National Examination. Most of them thought that the absence of the National Examination gave a comfortable impression in learning to students, students could focus more on learning-centered learning according to the schools in their area and students would certainly be more relaxed in what fields they mastered without having to focus on subjects in the national exam only. They will be able to further develop themselves according to their respective skills. National standards that are made nationally regardless of the area of the students will make students confused or even stressed. They argue that learning on the basis of desire is better than learning under pressure.

Students learn a lot of subjects in school, while in the national exam only a few subjects are entered, of course they feel confused. Then, what is the use of other lessons learned if they are not so important and are not included in the reference for student graduation. Actually the effectiveness of the assessment depends on the teacher and the awareness of the students, it does not need to be determined by a national examination with a national standard, while the quality of education and the needs of students in each school, in each region of course are different. They hope that the substitute for the national exam is a non-national standardized exam.

The national exam has become a negative mindset for students so that with the decision of the Ministry of Education and Culture (Kemendikbud) to abolish the national exam (UN) and the equivalence exam in 2021, it is 
stated in the Circular Letter (SE) of the Minister of Education and Culture Number 1 of 2021 concerning the Elimination of National Examinations and Exams. Equality and Implementation of School Exams in an Emergency Period The spread of Corona Virus Disease (Covid-19) is a good thing for students to be passionate about their passion in learning and no longer make students depressed and panicked.

\section{Acknowledgements}

The researchers thank Dr. Salasiah A, S.Pd., M.Ed. TESOL-Int for her advice and suggestions for the completion of this research. The researchers also express gratitude to the Annual Seminar on English Langauge Studies (ASELS) 2021 Conference committee that inspires us to continue to explore our potentials through the procurement of its annual conference agenda.

\section{References}

[1] S. Gultom. (2012). "Ujian Nasional Sebagai Wahana Evaluasi Pengembangan Pendidikan Karakter Bangsa" [Online]. Available: https://scholar.google.co.id/scholar?hl=id\&as_sdt=0, 5\&cluster=16553892234889285464

[2] Tilaar. (2006). "BAB II-Pengertian Ujian Nasional" [Online]. Available: http://digilib.uinsby.ac.id/839/3/ $\mathrm{Bab} \% 202$.pdf

[3] Mardapi. (2015). "MENENTUKAN KRITERIA KETUNTASAN MINIMALBERBASIS PESERTA DIDIK". JURnal Penelitian Dan Evaluasi Pendidikan [Online]. e-ISSN:2338-6061. Available: https://journal . uny . ac .id/index . php/jpep/article/view/4553/3913

[4] CNN Indonesia. (2019, Dec. 11). Nadiem Abolishes National Examination Starting 2021 [Online]. Available: https : //www.cnnindonesia.com/nasional/20191211112022-20-455978/nadiem-hapus-ujian-nasional-mulai-2021

[5] E. Airlangga, Marzuki, E Bachtiar, F Zuhriyatun, AMV Purba. (2021). COVID-19: Seribu Satu Wajah [Online]. Available: https://books . google.co.id/books?hl=en\&lr=\&id=HuAZAAAQBAJ\&Oi=fnd\&pg=PR15\&ots=Y67iHHbZr8\& sig=77fGnYf4ZXLx2g-NPUedZ_uKpwk\&redir_esc=y\#v=onepage\&q\&f=false

[6] D.N. Yuzar. (2021, May 9). Penyakit Menular dan Wabah Penyakit Covid-19 [Online]. Available: https://osf . io/5bqvw/

[7] W. D. Yulianto, \& L. Al Mubarokah. (2020). "Students' Moral Problem based on Teacher's Perspective: Imam Al Ghazali's Concept" [Online]. Available: https://www.scribd.com/document/453162458/ Students-Moral-Problem-Based-on-Teacher-s-Perspective-Imam-Al-Ghazali-s-Concept

[8] GD. Althof. (2021, Oct. 31). Pengertian Google Meet [Online]. Available: https://tochangeit.com/ pengertian-google-meet/

[9] LP2M UMA, Creswell. (2013) (2020, Nov. 21). Qualitative Reasearch Method [Online]. Available: https://1p2m. uma.ac.id/qualitative-research-methods-objectives-characteristics-and-strategies/

[10] Salmaa, Moleong. (2007:6) (2021, Jul. 1). Metode Penelitian kualitatif [Online]. Available: https:// penerbitdeepublish.com/metode-penelitian-kualitatif/ 